\title{
Aspidosperma species as sources of anti-malarials: uleine is the major anti-malarial indole alkaloid from Aspidosperma parvifolium (Apocynaceae)
}

Maria Fâni Dolabela1, Marinete Marins Póvoa², Geraldo Célio Brandão ${ }^{3}$, Fabíola Dutra Rocha4, Luciana Ferreira Soares ${ }^{5}$, Renata Cristina de Paula ${ }^{5}$ and Alaíde Braga de Oliveira ${ }^{1,5^{*}}$

\begin{abstract}
Background: Several species of the genus Aspidosperma (Apocynaceae) are used for the treatment of human malaria in Brazil and other meso- and South American countries.

Methods: Ethanol extract from Aspidosperma parvifolium trunk bark was submitted to acid-base extractions leading to alkaloid and neutral fractions. The alkaloid fraction was chromatographed over a silica gel column. Ethanol extract, fractions and uleine were analysed by HPLC-DAD, UPLC-ESI-MS/MS and HPLC-ESI-MicroTOF-MS. The anti-malarial activity was assayed against resistant and sensitive chloroquine Plasmodium falciparum strains by microscopic, $\left.{ }^{3} \mathrm{H}\right]-$ hypoxanthine incorporation and HRPII techniques. Cytotoxicity $\left(\mathrm{CC}_{50}\right)$ was evaluated against Vero and HepG2 cell lines by the MTT technique; selectivity indexes $\left(\mathrm{SI}=\mathrm{CC}_{50} / \mathrm{IC}_{50}\right)$ were calculated.

Results: The major peak in the HPLC-DAD chromatograms of the ethanol extract, alkaloid and neutral fractions suggested the presence of uleine that was isolated from the alkaloid fraction by column chromatography and was characterized by spectroscopic methods. A total of 15 alkaloids, besides uleine, were identified in the alkaloid fraction by UPLC-DAD-ESI-MS/MS and HPLC-ESI-MicroTOF-MS. The ethanol extract from Aspidosperma parvifolium and the neutral fraction were moderately active against $P$. falciparum strains. The alkaloid fraction and uleine disclosed high anti-malarial activity against chloroquine-resistant $P$. falciparum strain $\left(I_{50}<1 \mu \mathrm{g} / \mathrm{mL}\right)$. The ethanol extract, neutral fraction and uleine showed low cytotoxicity against Vero and HepG2 cell lines $\left(\mathrm{CC}_{50}>300 \mu \mathrm{g} / \mathrm{mL}\right)$. The alkaloid fraction showed moderate cytotoxicity to HepG2 cell line $\left(\mathrm{CC}_{50}=74.4 \mu \mathrm{g} / \mathrm{mL}\right)$. High SI values $(>10)$ were determined for all samples.
\end{abstract}

Conclusion: Ethanol extract from Aspidosperma parvifolium trunk bark afforded uleine that is the major constituent of the alkaloid fraction and disclosed a good in vitro anti-malarial activity. Moreover, 15 other indole alkaloids have been identified along with uleine.

Keywords: Anti-malarial activity, Plasmodium falciparum, Alkaloids, Uleine, Apocynaceae, Aspidosperma parvifolium

\footnotetext{
*Correspondence: alaidebraga@terra.com.br

1 Programa de Pós-Graduação em Ciências Farmacêuticas, Instituto de Ciências da Saúde, Universidade Federal do Pará, Belém, PA 66075-110, Brazil

Full list of author information is available at the end of the article
} 


\section{Background}

Globally, 3.3 billion people are at risk of malaria, a disease endemic to more than 100 countries. According to latest estimates, 198 million cases of malaria and 584,000 deaths occurred in 2013; $90 \%$ of all malaria deaths occurred in Africa and $78 \%$ of all deaths in children under 5 years old [1]. The extensive use of antimalarial drugs has imposed a high selective pressure on parasites, leading to the emergence of drug resistance, particularly in Plasmodium falciparum [2]. Plasmodium falciparum resistance to artemisinins has been detected in four countries of the Southeast Asia region. Artemisinin derivatives comprise the therapeutic scheme recommended for malaria treatment [3]. This points to the urgency for the development of new anti-malarial drugs. Plants continue to be a valuable source of bioactive compounds and investigation of traditional medicines used to treat malaria in endemic countries has afforded useful anti-malarial drugs, such as quinine, artemisinins and atovaquone [4-6].

Representatives of the genus Aspidosperma (family Apocynaceae, tribo Plumeriae) are found exclusively in the New World, from Mexico to Argentina [7], and several species have been traditionally used for the treatment of human malaria [8-11]. A recent review of the traditional use and anti-malarial activity of Aspidosperma species revealed several scientific bibliographical references on the use of 24 species to treat malaria/fevers, including Aspidosperma parvifolium, and to 19 Aspidosperma species that have had their extracts and/or alkaloids evaluated for in vitro and/or in vivo anti-malarial activity showing positive results. Only 20, out of more than 200 known indole alkaloids from Aspidosperma species have been assayed for anti-malarial activity, and variable levels of parasite inhibition have been reported [12].

Aspidosperma parvifolium is a tree of $10-15 \mathrm{~m}$ height, with a trunk diameter of $40-60 \mathrm{~cm}$. It reaches approximately $4 \mathrm{~m}$ height in about 2 years when growing in the field and it is valuable as timber [13]. Its popular names in Brazil are peroba, pau-pereira, guatambu, guatamburosa, guatambu branco, guatambu-oliva, guatambumarfim, amarelão $[13,14]$.

Uleine, 3-epi-uleine, apparicine, $\mathrm{N}$-demethyluleine, lupeol, and stigmasterol were previously isolated from the trunk bark of Aspidosperma parvifolium [15]. Uleine stimulated a maximum nitric oxide production in the concentrations of $0.1 \mu \mathrm{g} / \mathrm{mL}(20.9 \pm 1.4 \mu \mathrm{M})$ and $1 \mu \mathrm{g} /$ $\mathrm{mL}(41.1 \pm 0.2 \mu \mathrm{M})[16]$ and exhibited high level of acetylcholinesterase inhibition [17]. Uleine was evaluated for cytotoxicity against 65 cancer cell lines panel and it was inactive in all of them [18].

The present paper reports on the anti-malarial activity of Aspidosperma parvifolium against chloroquine-resistant (W2) and sensitive (3D7) P. falciparum strains. Moreover, phytochemical studies and cytotoxicity evaluations are also described.

\section{Methods}

\section{Plant material, extraction and phytochemical studies}

Trunk bark of Aspidosperma parvifolium was collected in the municipality of Paracatu, Minas Gerais, Brazil. A dried specimen was deposited in the Herbarium of the Universidade Federal de Minas Gerais (UFMG), Belo Horizonte, Minas Gerais, Brazil (voucher number BHCB60345). Plant bark was dried in an oven with circulating air at $40{ }^{\circ} \mathrm{C}$ and milled. Powdered plant bark $(2.5 \mathrm{~kg})$ was extracted by percolation with ethanol $96{ }^{\circ} \mathrm{GL}$. The extractive solution was concentrated in a rotary evaporator to give the crude ethanol extract (240 g, $9.6 \%)$. An aliquot of ethanol extract $(55.2 \mathrm{~g})$ was suspended in aq. $\mathrm{HCl} 1 \mathrm{~N}(500 \mathrm{~mL})$ and was extracted with dichloromethane $(5 \times 200 \mathrm{~mL})$. The organic solvent was removed in a rotary evaporator affording the neutral fraction $(8.7 \mathrm{~g})$. The aqueous solution was made alkaline (pH 10) with conc. ammonium hydroxide, followed by extraction with dichloromethane $(5 \times 200 \mathrm{~mL})$. Solvent concentration in a rotary evaporator afforded the alkaloid fraction $(3.8 \mathrm{~g})$. Part of the alkaloid fraction $(1.0 \mathrm{~g})$ was chromatographed in a silica gel column eluted with solvents and mixtures of solvents of increasing polarities. Fractions eluted with ethyl acetate-methanol were combined (507 $\mathrm{mg}$ ) and chromatographed on a silica gel column affording uleine as white crystals $(49 \mathrm{mg})$.

The ethanol extract, alkaloid fraction, neutral fraction, and uleine were analysed by high performance liquid chromatography with diode array detector (HPLC-DAD, Waters mod. 2695, USA), C-18 reverse phase column $(5 \mu \mathrm{m}, 125 \times 45 \mathrm{~mm}$, LiChrocart 125-4, Merck, Germany), at $40{ }^{\circ} \mathrm{C}$, flow rate of $1 \mathrm{~mL} / \mathrm{min}$, wavelengths scanning from 220 to $400 \mathrm{~nm}$. The mobile phases were a buffer solution $\mathrm{pH} 5.0$ of acetic acid with $0.2 \%$, triethylamine (A) and acetonitrile (B) in the following programme of elution: $t=0 \mathrm{~min}, \mathrm{~A}=90 \% ; \mathrm{t}=10 \mathrm{~min}$, $\mathrm{A}=80 \% ; \mathrm{t}=30 \mathrm{~min}, \mathrm{~A}=50 \%$; $=35 \mathrm{~min}, \mathrm{~A}=90 \%$. After 35 min acetonitrile $95 \%$ was used for $10 \mathrm{~min}$ to wash the column.

Analyses by ultra-performance liquid chromatography coupled to UV and mass spectrometry by electron spray ionization (UPLC-DAD-ESI-MSMS) were performed in an Acquity $\mathrm{H}$-Class Core System ${ }^{\circledR}$ Waters equipment; the positive mode was used for ESI-MSMS, with capillary voltage of $3.5 \mathrm{eV}$, the cone $60 \mathrm{eV}$, CSH130 C-18 column (particles of $1.7 \mu \mathrm{m}, 50 \times 3 \mathrm{~mm}$ ), flow of $0.3 \mathrm{~mL} /$ min, temperature of $40{ }^{\circ} \mathrm{C}$ and UV detection between 220 and $400 \mathrm{~nm}$. As mobile phase, a linear gradient was used, in which the initial time contained aqueous solution of 
formic acid $0.1 \%$ (A) and acetonitrile with formic acid $0.1 \%$ (B), in 10 min $5 \%$ of A and $95 \%$ B. Operating parameters of the mass spectrometer were capillary temperature $250{ }^{\circ} \mathrm{C}$; spray needle voltage set at $3.50 \mathrm{kV}$; ES capillary voltage +3 and $-47 \mathrm{~V}$ for positive and negative polarity, respectively; tube lens offset 0 and $-25 \mathrm{~V}$ for positive and negative polarity, respectively. Nitrogen was used as a sheath gas with a flow of 50 arbitrary units. Mass analyses were carried out in full-scan mode from 100 to $1500 \mathrm{Da}$, in both positive and negative mode. UV spectra (200$400 \mathrm{~nm}$ ) from the main peaks were registered on line.

Uleine was identified on the basis of spectroscopic methods (Ultraviolet/UV, Infra-red/IR, ${ }^{1} \mathrm{H}$ and ${ }^{13} \mathrm{CNMR}$ (Hydrogen and Carbon-13 Nuclear Magnetic Resonance) and direct comparison with authentic sample previously isolated at UFMG [15].

\section{Anti-malarial activity}

Plasmodium falciparum W2 (resistant to chloroquine) and 3D7 (sensitive to chloroquine) strains were maintained in continuous culture in human erythrocytes (blood group $\mathrm{O}+$ ) in RPMI medium supplemented with $10 \%$ human plasma (complete medium) [19]. Synchronization of parasites was achieved by sorbitol treatment [20] and parasitaemia was microscopically determined in Giemsa-stained smears.

\section{In vitro growth inhibition of Plasmodium falciparum (W2 and 3D7) by the microscopic method}

Parasites in the trophozoite stage were used (parasitaemia of $1 \%$ and haematocrit of $0.5 \%$ ) and different concentrations of test samples $(\leq 100 \mu \mathrm{g} / \mathrm{mL})$. Chloroquine was used as a standard anti-malarial drug. After $72 \mathrm{~h}$ of incubation under $\mathrm{CO}_{2}$, stained with Giemsa were prepared.

The antiparasitic effects of the extracts/fractions/compounds were measured by the per cent inhibition of parasite growth in relation to the control (parasites cultivated in drug-free medium) [21]. The $50 \%$ inhibitory concentrations $\left(\mathrm{IC}_{50}\right)$, compared to the drug-free control responses, were estimated by linear interpolation [22]. Each experiment was performed in triplicate and repeated three times. The blood smears were read in a double-blind manner. The $\mathrm{IC}_{50}$ was determined by means of linear regression curve. The following criteria being adopted: $\mathrm{IC}_{50} 10 \mu \mathrm{g} / \mathrm{mL}$, good activity; $\mathrm{IC}_{50}>100 \mu \mathrm{g} / \mathrm{mL}$, inactive; $\mathrm{IC}_{50}$ of $10-50 \mu \mathrm{g} / \mathrm{mL}$, moderate activity; and, $\mathrm{IC}_{50}$ of $50-100 \mu \mathrm{g} / \mathrm{mL}$, low activity [23].

\section{In vitro growth inhibition of Plasmodium falciparum (W2 and 3D7) by $\left[{ }^{3} \mathrm{H}\right]$-hypoxanthine incorporation}

Trophozoite stage parasites ( $1 \%$ parasitaemia and $0.5 \%$ haematocrit), different concentrations of test samples $(\leq 100 \mu \mathrm{g} / \mathrm{mL})$ and chloroquine as standard anti-malarial drug were used in the assays. After $24 \mathrm{~h}$ incubation period, $25 \mu \mathrm{L}$ of medium containing $\left[{ }^{3} \mathrm{H}\right]$-hypoxanthine $(0.5 \mu \mathrm{Ci} /$ well $)$ (PerkinElmer) was added per well, followed by another $18 \mathrm{~h}$ incubation at $37{ }^{\circ} \mathrm{C}$ [24]. The cells were harvested (Cell Harvester PerkinElmer) on glass fibre filters (Filtermat A, PerkinElmer) then placed onto sample bags (PerkinElmer) and immersed in scintillation fluid (UltimaGold, PerkinElmer). Radioactive emission was counted in a 1450 Microbeta TriLux Microplate Scintilation and Luminescence Counter (PerkinELmer). The inhibition of parasite growth was evaluated from the levels of $[3 \mathrm{H}]$-hypoxanthine incorporation, i.e., $\mathrm{IC}_{50}$ values were evaluated by comparing the incorporation in drug-free control cultures and estimated by linear interpolation [25] using curve fitting software (Microcal Origin software 8.5). All experiments were performed three times, and each sample was tested in triplicate.

\section{In vitro growth inhibition of Plasmodium falciparum (W2) by HRPII method}

HRPII assays were performed as previously described [26]. Briefly, cultures of $P$. falciparum (1.5\% haematocrit, $0.05 \%$ parasitaemia) were placed in 96-well microplates with the extracts/fractions/compounds and controls at different concentrations, and were incubated for $48 \mathrm{~h}$ at $37{ }^{\circ} \mathrm{C}$. After $24 \mathrm{~h}$ incubation, the content of six wells corresponding to medium and no test sample controls were harvested and frozen in microtubes, to allow subtracting the average value obtained from these wells from the other wells for excluding the background value (production of HRP2 during the first $24 \mathrm{~h}$ of incubation). After a total of $48 \mathrm{~h}$ incubation, the plates were frozen and thawed twice for total erythrocyte lyses and $100 \mu \mathrm{L} /$ well of the material was placed in another plate for the ELISA test. This plate was pre-coated overnight at $4{ }^{\circ} \mathrm{C}$ with $1 \mathrm{mg} / \mathrm{ml}$ of the primary antibody anti-HRPII (MPFM-55A ICLLABs) and then the content was discarded, replaced by the blocking solution (PBS/BSA $2 \%$ $200 \mu \mathrm{l} /$ well), incubated for $2 \mathrm{~h}$, and finally the content was discarded. The haemolyzed cultures were transferred to the ELISA pre-coated plate, incubated ( $1 \mathrm{~h}$, room temperature), discarded, incubated for $1 \mathrm{~h}$ with $0.05 \mathrm{mg} / \mathrm{mL}$ of the secondary antibody (MPFG55P-ICLLAB; $100 \mu \mathrm{L} /$ well), then incubated with $100 \mu \mathrm{L} /$ well of TMB chromogen (15 min at room temperature) in the dark. The reaction was stopped with $50 \mathrm{~mL} / \mathrm{L}$ of $1 \mathrm{M}$ sulfuric acid and the absorbance was read at $450 \mathrm{~nm}$ in a spectrophotometer (Infinite ${ }^{\circledR} 200$ PRO, Tecan). The results were evaluated with the software MicrocalOrigin 8.5 for determination of the dose-response curves plotted with sigmoidal fit. The $50 \%$ inhibitory concentration growth of the parasites 
$\left(\mathrm{IC}_{50}\right)$ was determined by comparison with controls with standard drug and without drugs.

\section{Cytotoxicity assays}

Cell viability was determined by the MTT [3- (4,5dimethyltrazol-2-yl)-2,5-diphenyl tetrazolium bromide] method according to Mosman [27]. HepG2 A16 cells and Vero $\left(4 \times 10^{5}\right.$ cells $\left./ 0.1 \mathrm{~mL}\right)$ were grown in RPMI1640 (Roswell Park Memorial Institute 1640) medium (Sigma Aldrich $^{\circledR}$, USA), supplemented with $5 \%$ of fetal calf serum, kept in a $5 \% \mathrm{CO}_{2}$ atmosphere at $37{ }^{\circ} \mathrm{C}$. The ethanol extract from Aspidosperma parvifolium, fractions and uleine were solubilized in RPMI-1640 and dimethyl sulfoxide $(0.02 \%, \mathrm{v} / \mathrm{v})$. After $24 \mathrm{~h}$, the solution was added at different concentrations (in $\mu \mathrm{g} / \mathrm{mL}: 1,10$, $100,1000)$, followed by $24 \mathrm{~h}$ of further incubation. The MTT $(2.0 \mathrm{mg} / \mathrm{mL})$ was added, followed by incubation at $37{ }^{\circ} \mathrm{C}$ in an atmosphere of $5 \% \mathrm{CO}_{2}$ for $4 \mathrm{~h}$. Dimethyl sulfoxide was added to each well to solubilize the formazan crystals. The optical density was determined at $492 \mathrm{~nm}$ (Vero cells) and $570 \mathrm{~nm}$ (HepG2 cells; Stat Fax 2100 microplate reader, Awareness Technology, Inc, USA). The cell viability was expressed as a percentage of the control absorbance in the untreated cells after subtracting the appropriate background and the average cytotoxic concentration $\left(\mathrm{CC}_{50}\right)$ was determined by linear regression. Samples with $\mathrm{CC}_{50}>200 \mu \mathrm{g} / \mathrm{mL}$ were considered of low cytotoxicity. Selectivity index (SI) for the anti-malarial activity was then calculated based on the rate between $\mathrm{CC}_{50}$ and $\mathrm{IC}_{50}$ for the in vitro activity against $P$. falciparum [28].

\section{Results}

\section{Phytochemical studies}

HPLC-DAD chromatograms showed a peak for the same major component in the ethanol extract $(\mathrm{RT}=30.1 \mathrm{~min}$; Fig. 1a), alkaloid fraction ( $R T=29.6 \mathrm{~min}$, Fig. $1 \mathrm{~b})$ and neutral fraction $(\mathrm{RT}=29.8 \mathrm{~min}$, Fig. 1c) that might correspond to uleine (Fig. 1d). The UV spectra are suggestive of indole alkaloid [29] (Fig. 1a-d).

The on-line UPLC-DAD chromatogram of the alkaloid fraction shows also a predominant peak $(\mathrm{RT}=3.49 \mathrm{~min})$ (Fig. 2) related to indole alkaloids (Fig. 2). This peak must correspond to the most intense one in Fig. 1a-c. The difference in retention times (RT) is a consequence of the different mobile phases used in the experiments as well as to the different equipments in each case, HPLC and UPLC.

The UPLC-ESI-MS spectrum of the alkaloid fraction disclosed distinct peaks for uleine and 3-epi-uleine, demonstrating that superposition of these alkaloids peaks was occurring in Figs. 1a-c and 2. This behaviour is a consequence of the close polarity of these two molecules that are just epimers at $\mathrm{C}-3$ position and explains the difficulty for isolation of pure uleine although being the major alkaloid fraction constituent. Further analyses of the alkaloid fraction was performed by tandem mass spectrometry (UPLC-ESI-MS/MS) (Fig. 3), a variant of HPLC that affords significant advantages in resolution, speed, and sensitivity for analytical determinations, particularly when coupled to mass spectrometers capable of highspeed acquisitions allowing studies on the fragmentations of each component under electron spray conditions [30]. The observed mass fragments (Table 1) are consistent with the structural classes of these alkaloids that belong to the aspidospermane and plumerane types, [3134] and full fragmentation mechanisms will be published elsewhere. Only six out of the 16 alkaloids identified have been previously isolated from Aspidosperma parvifolium, e.g., $N$-methyltetrahydroellipticine, uleine, 3-epi-uleine, $\mathrm{N}$-demethyluleine, $\mathrm{N}$-demethyl-dihydrouleine, and apparicine [15, 35] (Fig. 4).

The chemical structure of uleine was characterized by spectroscopic data (UV, IR, MS and NMR) in comparison with literature data $[15,28,36]$ and its identification was confirmed by direct comparison with authentic sample that was previously isolated at UFMG [15].

\section{Anti-malarial activity}

The ethanol extract of Aspidosperma parvifolium trunk bark disclosed a good in vitro activity against $P$. falciparum W2 strain by the HRPII assay $\left(\mathrm{IC}_{50}=10.11 \pm 2.22 \mu \mathrm{g} / \mathrm{mL}\right)$ and a moderate activity by the microscopic method against parasite W2 and $3 \mathrm{D} 7$ strain $\left(\mathrm{IC}_{50}=32.75 \pm 1.06\right.$ and $20.51 \pm 0.70 \mu \mathrm{g} /$ $\mathrm{mL}$, respectively). Higher $\mathrm{IC}_{50}$ values were determined by the $\left[{ }^{3} \mathrm{H}\right]$-hypoxanthine method against $\mathrm{W} 2$ and $3 \mathrm{D} 7$ strains $\left(\mathrm{IC}_{50}=42.51 \pm 6.33\right.$ and $38.20 \pm 0.33 \mu \mathrm{g} /$ $\mathrm{mL}$, respectively) (Table 2). The neutral fraction was active against parasite W2 strain by the HRPII method $\left(\mathrm{IC}_{50}=9.71 \mu \mathrm{g} / \mathrm{mL}\right)$ and its $\mathrm{IC}_{50}$ was close to that one of the ethanol extract $\left(\mathrm{IC}_{50}=10.11 \pm 2.22 \mu \mathrm{g} / \mathrm{mL}\right)$ against the same parasite strain. The alkaloid fraction and uleine were very active disclosing close $\mathrm{IC}_{50}$ values against the parasite W2 strain by the three methods, the lowest value being determined by the microscopic method: $0.98 \pm 0.20$ and $0.75 \pm 0.10 \mu \mathrm{g} / \mathrm{mL}$, respectively. Higher $\mathrm{IC}_{50}$ values were determined for all the samples against W2 parasite by the radioisotopic method than by the microscopic method and it was approximately ten-fold higher for the alkaloid fraction and uleine. For the purpose of comparison, the data on the anti-malarial activity of apparicine, aspidocarpine, and ellipticine, the only previously assayed alkaloids $[37,38]$ out of the 16 here identified in Aspidosperma parvifolium, are included in Table 2. 

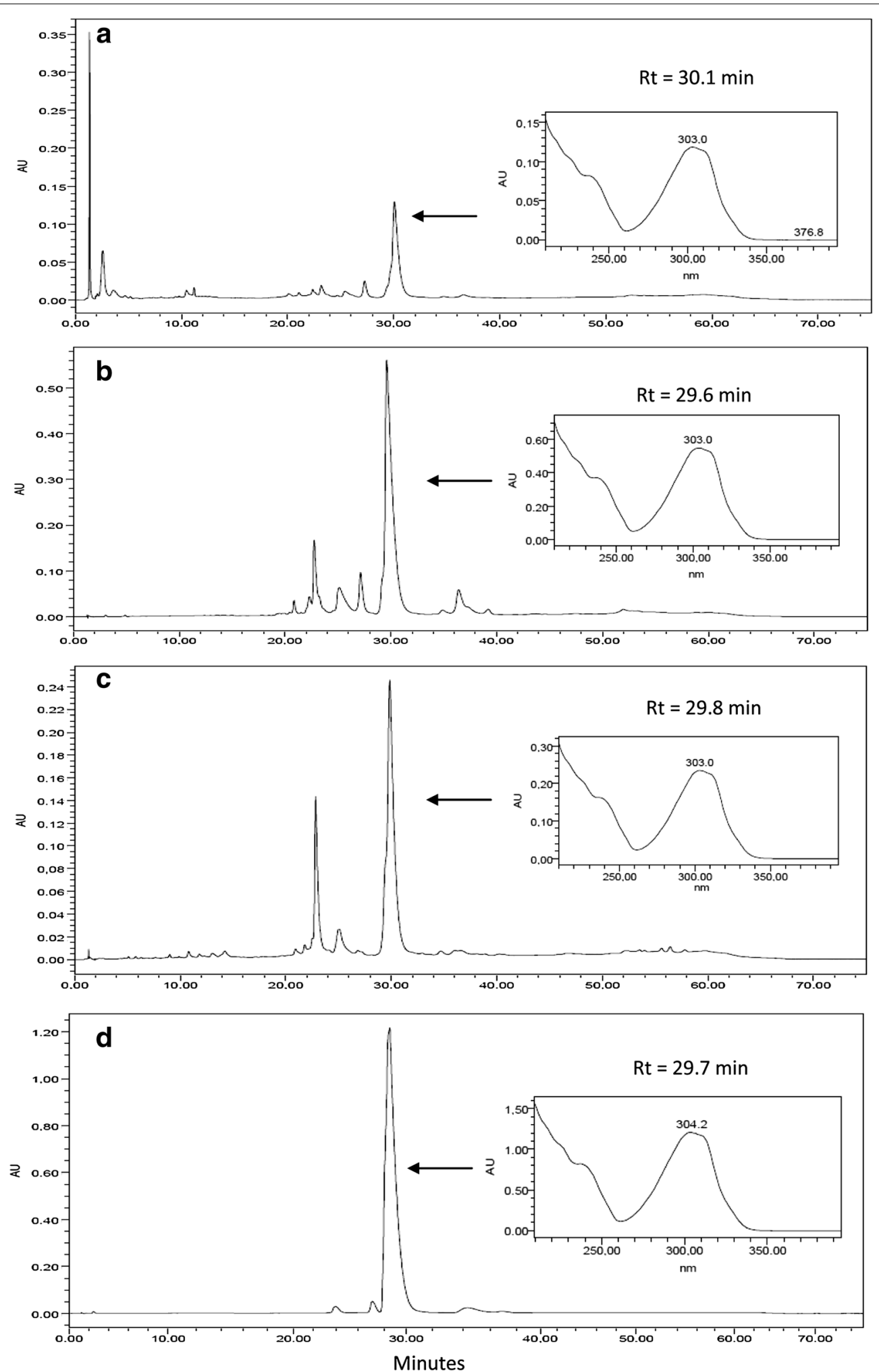

Fig. 1 HPLC-DAD profiles of Aspidosperma parvifolium trunk bark ethanol extract and fractions. a Trunk bark ethanol extract (EEAP); b alkaloid fraction (EEAPA); c neutral fraction (EEAPN); d uleine 


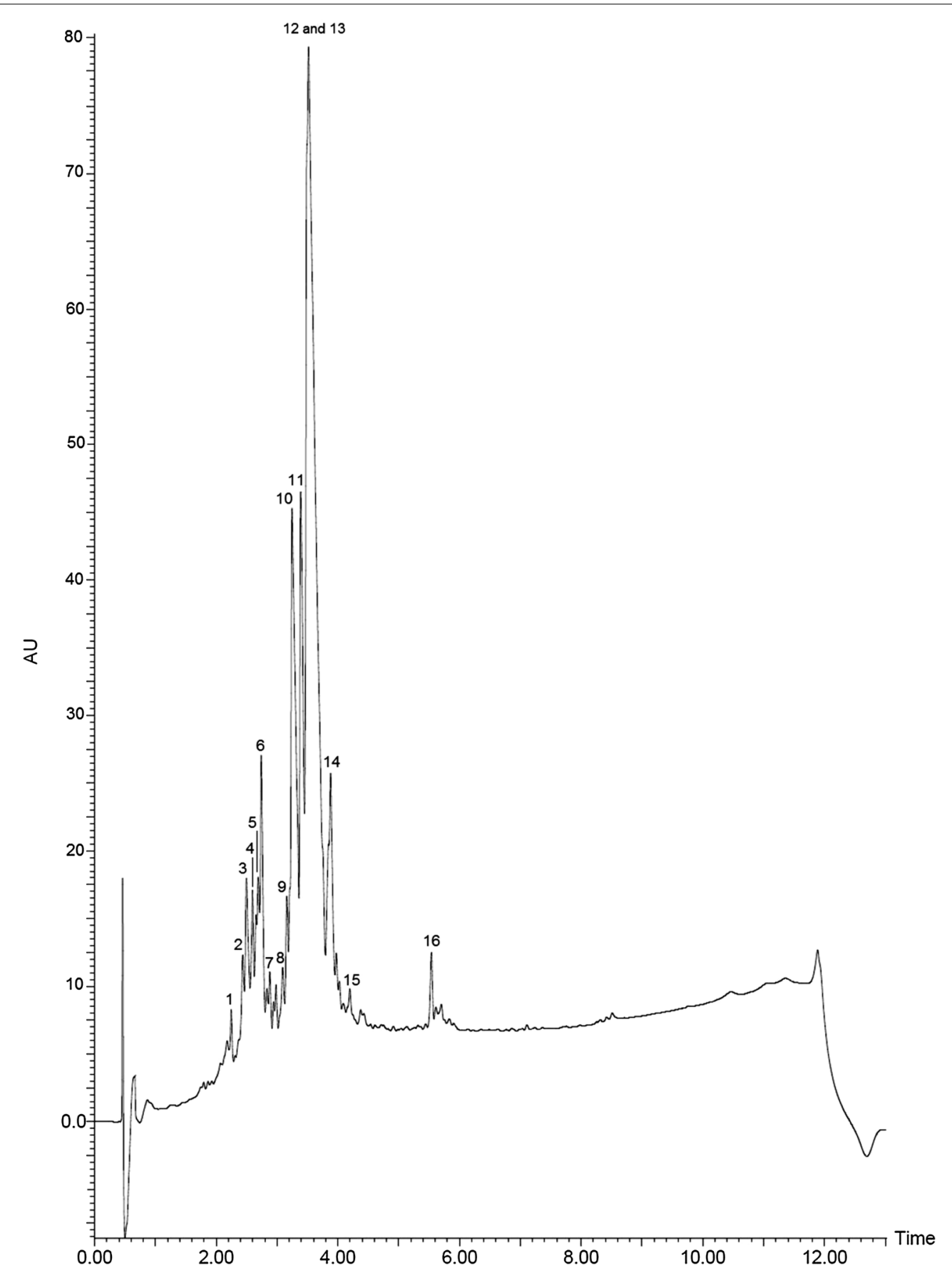

Fig. 2 UPLC-DAD profile of Aspidosperma parvifolium trunk bark alkaloid fraction. (1) Spegazzinidine, (2) 1,13-Dihydro-13-hydroxyuleine, (3) aspidocarpine, (4) deacetylaspidospermine, (5) pyrifolidine, (6) 1-methyldeacetylaspidospermidine, (7) dasycarpidone, (8) aspidospermidin-19-ol, (9) N-acetylaspidospermidine, (10) N-demethyluleine, (11) apparicine, (12) uleine, (13) 3-epi-uleine, (14) aspidospermine, (15) dasycarpidol, (16) dasycarpidan

Differences in the $\mathrm{IC}_{50}$ values for the microscopic method and the radioisotopic assay might be related to the time of incubation of the parasites with the samples: 72 and $42 \mathrm{~h}$, respectively. However, for the radioisotopic assay and the HRPII method that has had similar incubation times, an important factor that might explain these differences, might be the intrinsic sensitivity of each technique. Interestingly, higher potency was generally observed against parasite W2 strain, which is chloroquine resistant, than against the 3D7 strain, a 


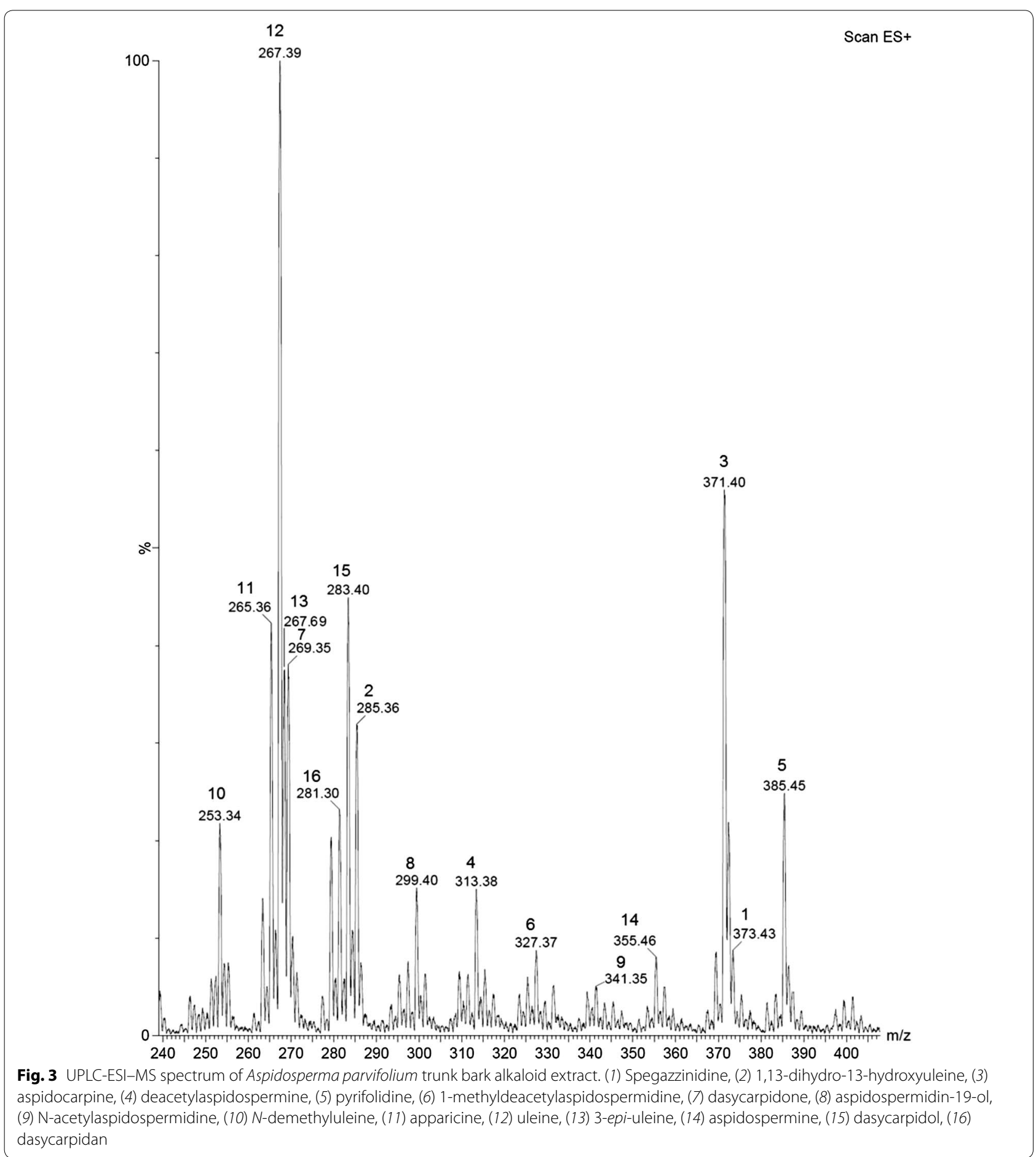

chloroquine-sensitive $P$. falciparum strain, except for the ethanol extract.

The relatively close $\mathrm{IC}_{50}$ values for the neutral fraction and the crude ethanol extract (Table 2) could be explained by the fact that alkaloids are still present in the neutral fraction indicating that the acid-base process used for extraction of alkaloids from the ethanol extract was not complete, as is shown by the HPLC-DAD chromatogram (Fig. 1c).

It is interesting to call attention for the fact that, only three (apparicine, aspidocarpine and ellipticine) out of the 16 identified alkaloids in the trunk bark of 
Table 1 Alkaloids identified in Aspidosperma parvifolium trunk bark alkaloid extract by UPLC-DAD-ESI-MS/MS and HPLCESI-MICROTOF-MS

\begin{tabular}{|c|c|c|c|c|c|c|}
\hline Compounds & $\begin{array}{l}\text { Peak } \\
\text { number }\end{array}$ & $\begin{array}{l}\text { Rt (min) } \\
\text { UPLC-ESI-MS }\end{array}$ & $\begin{array}{l}\text { UV } \lambda_{\max }(\mathrm{nm}) \\
\text { UPLC-DAD }\end{array}$ & $\begin{array}{l}{[\mathrm{M}+\mathrm{H}]^{+}} \\
\text {UPLC-ESI-MS } \\
(\mathrm{m} / \mathrm{z})\end{array}$ & $\begin{array}{l}\text { HRMS HPLC-ESI- } \\
\text { MICROTOF-MS } \\
(\mathrm{m} / \mathrm{z})\end{array}$ & $\begin{array}{l}\text { UPLC-ESI-MS/MS } \\
\text { fragments }(\mathrm{m} / \mathrm{z})\end{array}$ \\
\hline Spegazzinidine & 1 & 2.06 & 317.13 & 373.43 & & $\begin{array}{l}373.11,354.90,341.10 \\
323.90,311.42,295.0 \\
279.10,247.79,231.91 \\
205.95,183.71,124.07 \\
108.86\end{array}$ \\
\hline $\begin{array}{l}\text { 1,13-Dihydro-13- hydroxy- } \\
\text { uleine }\end{array}$ & 2 & 2.26 & 316.13 & 285.36 & 285.1949 & $\begin{array}{l}285.11,254.11,238.10 \\
236.29,210.16,208.0 \\
206.01,197.97,195.15 \\
182.15,168.15,167.02 \\
155.96,144.02,130.02 \\
124.07,121.89\end{array}$ \\
\hline Aspidocarpine & 3 & 2.50 & 304.13 & 371.40 & 371.1975 & $\begin{array}{c}371.22,353.95,339.21 \\
321.0,270.22,249.68 \\
245.90,227.69,220.13 \\
199.71,173.75,154.10 \\
152.08,142.88,107.97\end{array}$ \\
\hline Deacetylaspidospermine & 4 & 2.60 & 317.13 & 313.38 & 313.1953 & $\begin{array}{c}313.08,251.89,222.09 \\
206.08,180.12,168.03 \\
151.96,140.05,131.92\end{array}$ \\
\hline Pyrifolidine & 5 & 2.62 & 317.13 & 385.45 & - & $\begin{array}{c}385.14,367.12,353.07 \\
327.11,309.09,256.10 \\
231.97,167.89,121.07\end{array}$ \\
\hline $\begin{array}{l}\text { 1-Methyldeacetyl-aspidosper- } \\
\text { midine }\end{array}$ & -6 & 2.88 & 310.13 & 327.37 & 327.2061 & $\begin{array}{c}327.01,309.16,296.15 \\
283.14,278.30,252.21 \\
236.19,197.97,170.0 \\
168.24,130.72,129.21\end{array}$ \\
\hline Dasycarpidone & 7 & 2.74 & 319.13 & 269.35 & 269.1628 & $\begin{array}{l}\text { 238.16, 210.12, 209.04, } \\
\text { 192.16, 182.11, 167.06, } \\
\text { 130.01 }\end{array}$ \\
\hline Aspidospermidin-19-ol & 8 & 3.25 & 302.13 & 299.40 & 299.1806 & $\begin{array}{l}299.15,252.02,234.75 \\
233.75,221.33,208.10 \\
206.34,196.07,169.16 \\
159.39,150.07,138.03 \\
122.97,109.17\end{array}$ \\
\hline N-Acetylaspidospermidine & 9 & 3.27 & 303.13 & 341.35 & 341.1856 & $\begin{array}{c}341.15,322.96,309.17 \\
304.58,295.20,294.07 \\
281.29,266.8,251.90 \\
236.22,223.01,183.73 \\
168.12,121.86,107.82\end{array}$ \\
\hline Des-N-methyluleine & 10 & 3.35 & 304.13 & 253.34 & 253.1686 & $\begin{array}{l}236.10,221.10,208.09 \\
207.16,206.03,194.09 \\
193.03,182.03,181.03 \\
167.02\end{array}$ \\
\hline Apparicine & 11 & 3.39 & 303.13 & 265.36 & 265.1678 & $\begin{array}{c}265.11,250.02,236.12 \\
222.16,208.14,207.20 \\
206.09,194.12,180.0 \\
158.03,134.01,108.17\end{array}$ \\
\hline Uleine & 12 & 3.49 & 303.13 & 267.39 & 267.1845 & $\begin{array}{l}236.10,221.04,208.09 \\
207.09,206.16,193.03 \\
182.09,167.02\end{array}$ \\
\hline Epi-uleine & 13 & 3.53 & 304.13 & 267.69 & 267.1853 & $\begin{array}{l}236.16,221.04,208.09 \\
207.03,206.03,194.03 \\
193.03,182.03,181.03 \\
167.02\end{array}$ \\
\hline Aspidospermine & 14 & 3.63 & 297.13 & 355.46 & 355.1993 & $\begin{array}{l}355.14,323.30,313.08 \\
268.19,256.22,218.07 \\
173.81,164.17,124.01 \\
122.05\end{array}$ \\
\hline
\end{tabular}


Table 1 continued

\begin{tabular}{|c|c|c|c|c|c|c|}
\hline Compounds & $\begin{array}{l}\text { Peak } \\
\text { number }\end{array}$ & $\begin{array}{l}\text { Rt (min) } \\
\text { UPLC-ESI-MS }\end{array}$ & $\begin{array}{l}\text { UV } \lambda_{\max }(\mathrm{nm}) \\
\text { UPLC-DAD }\end{array}$ & $\begin{array}{l}{[\mathrm{M}+\mathrm{H}]^{+}} \\
\text {UPLC-ESI-MS } \\
(\mathrm{m} / \mathrm{z})\end{array}$ & $\begin{array}{l}\text { HRMS HPLC-ESI- } \\
\text { MICROTOF-MS } \\
(\mathrm{m} / \mathrm{z})\end{array}$ & $\begin{array}{l}\text { UPLC-ESI-MS/MS } \\
\text { fragments }(\mathrm{m} / \mathrm{z})\end{array}$ \\
\hline Dasycarpidol & 15 & 3.88 & 304.13 & 283.40 & 283.1793 & $\begin{array}{c}236.23,221.04,208.09 \\
207.09,206.16,193.09 \\
192.15,181.50,167.0\end{array}$ \\
\hline Dasycarpidan & 16 & 5.51 & 303.13 & 281.30 & - & $\begin{array}{l}281.05,236.07,222.08 \\
\quad 194.04\end{array}$ \\
\hline
\end{tabular}

(-) species not detected

$R$ t retention time, UV ultraviolet, UPLC-DAD-ESI-MS ultra performance liquid chromatography photo diode array electron spray mass spectrometry, HRMS high resolution mass spectrometry, HPLC-ESI-MICROTOF-MS high performance liquid chromatography electro spray ionization time-of-flight mass spectrometry

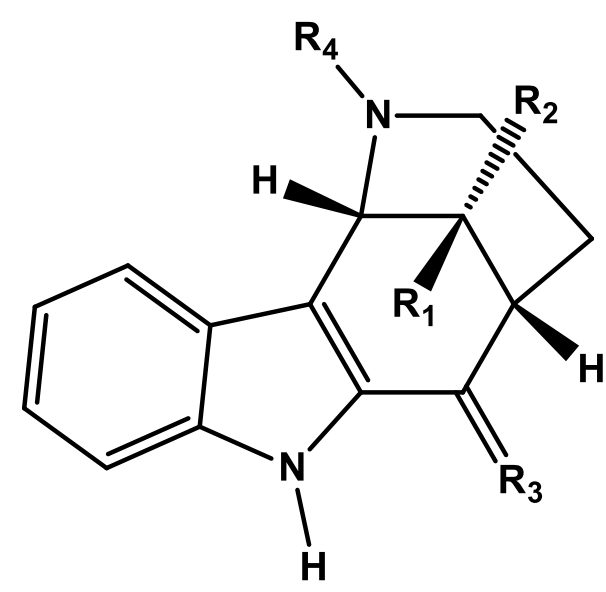

(2) $\mathrm{R}_{1}=\mathrm{CH}_{2} \mathrm{CH}_{3} ; \mathrm{R}_{2}=\mathrm{H} ; \mathrm{R}_{3}=\mathrm{H}$ and $\mathrm{CH}_{2} \mathrm{OH} ; \mathrm{R}_{4}=\mathrm{CH}_{3} 1,13-$ Dihydro-13-hydroxyuleine

(7) $\mathrm{R}_{1}=\mathrm{CH}_{2} \mathrm{CH}_{3} ; \mathrm{R}_{2}=\mathrm{H} ; \mathrm{R}_{3}=\mathrm{O} ; \mathrm{R}_{4}=\mathrm{CH}_{3}$ Dasycarpidone

(10) $\mathrm{R}_{1}=\mathrm{CH}_{2} \mathrm{CH}_{3} ; \mathrm{R}_{2}=\mathrm{R}_{4}=\mathrm{H} ; \mathrm{R}_{3}=\mathrm{CH}_{2}$ Des-N-methyluleine

(12) $\mathrm{R}_{1}=\mathrm{CH}_{2} \mathrm{CH}_{3} ; \mathrm{R}_{2}=\mathrm{H} ; \mathrm{R}_{3}=\mathrm{CH}_{2} ; \mathrm{R}_{4}=\mathrm{CH}_{3}$ Uleine

(13) $\mathrm{R}_{1}=\mathrm{H} ; \mathrm{R}_{2}=\mathrm{CH}_{2} \mathrm{CH}_{3} ; \mathrm{R}_{3}=\mathrm{CH}_{2} ; \mathrm{R}_{4}=\mathrm{CH}_{3}$ epi-Uleine

(15) $\mathrm{R}_{1}=\mathrm{CH}_{2} \mathrm{CH}_{3} ; \mathrm{R}_{2}=\mathrm{H} ; \mathrm{R}_{3}=\mathrm{H}$ and $\mathrm{OH} ; \mathrm{R}_{4}=\mathrm{CH}_{3}$ Dasycarpidol

(16) $\mathrm{R}_{1}=\mathrm{CH}_{2} \mathrm{CH}_{3} ; \mathrm{R}_{2}=\mathrm{H} ; \mathrm{R}_{3}=\mathrm{CH}_{2} ; \mathrm{R}_{4}=\mathrm{CH}_{3}$ Dasycarpidan

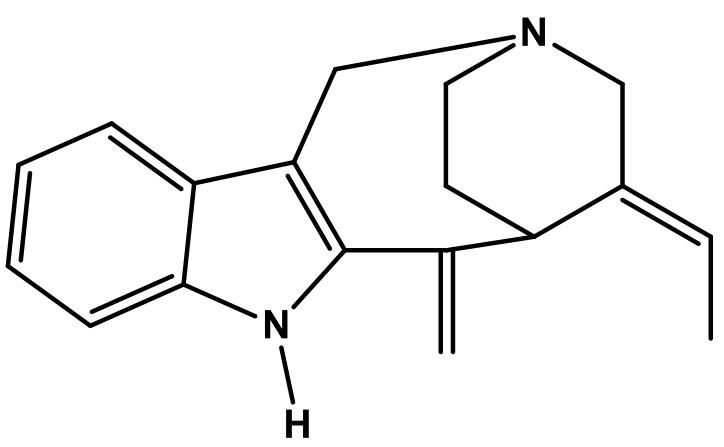

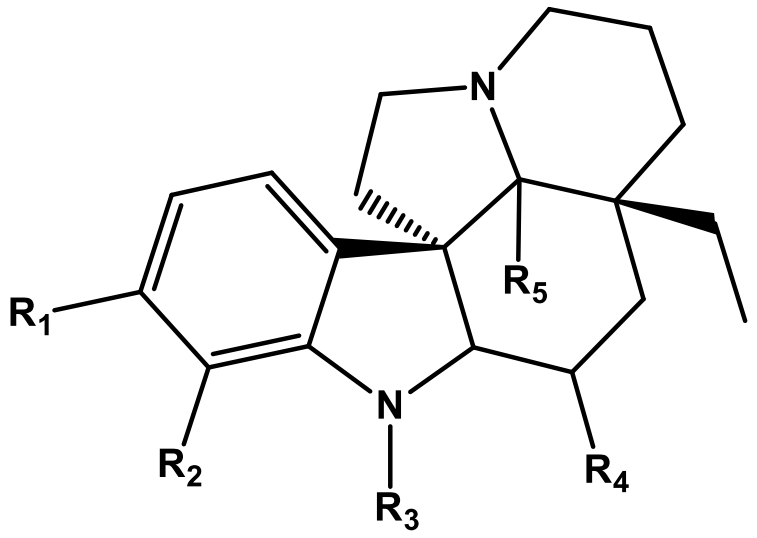

(1) $\mathrm{R}_{1}=\mathrm{R}_{2}=\mathrm{R}_{4}=\mathrm{OH} ; \mathrm{R}_{3}=\mathrm{CH}_{3} \mathrm{CO} ; \mathrm{R}_{5}=\mathrm{H}$ Spegazzinidine

(3) $\mathrm{R}_{1}=\mathrm{CH}_{3} \mathrm{O} ; \mathrm{R}_{2}=\mathrm{OH} ; \mathrm{R}_{3}=\mathrm{CH}_{3} \mathrm{O} ; \mathrm{R}_{4}=\mathrm{R}_{5}=\mathrm{H}$; Aspidocarpine

(4) $\mathrm{R}_{1}=\mathrm{R}_{3}=\mathrm{R}_{4}=\mathrm{R}_{5}=\mathrm{H} ; \mathrm{R}_{2}=\mathrm{CH}_{3} \mathrm{O}$ Deacetylaspidospermine

(5) $\mathrm{R}_{1}=\mathrm{R}_{2}=\mathrm{CH}_{3} \mathrm{O} ; \mathrm{R}_{3}=\mathrm{CH}_{3} \mathrm{CO} ; \mathrm{R}_{4}=\mathrm{R}_{5}=\mathrm{H}$ Pyrifolidine

(6) $\mathrm{R}_{1}=\mathrm{R}_{4}=\mathrm{R}_{5}=\mathrm{H} ; \mathrm{R}_{2}=\mathrm{CH}_{3} \mathrm{O} ; \mathrm{R}_{3}=\mathrm{CH}_{3}$ 1-metyldeacetyl-aspidospermidine

(8) $\mathrm{R}_{1}=\mathrm{R}_{2}=\mathrm{R}_{3}=\mathrm{R}_{4}=\mathrm{H} ; \mathrm{R}_{5}=\mathrm{OH}$ Aspidospermidin-19-ol

(9) $\mathrm{R}_{1}=\mathrm{R}_{2}=\mathrm{R}_{4}=\mathrm{R}_{5}=\mathrm{H} ; \mathrm{R}_{3}=\mathrm{CH}_{3} \mathrm{CO}_{2} \mathrm{~N}$-acetylaspidospermidine

(14) $\mathrm{R}_{1}=\mathrm{R}_{4}=\mathrm{R}_{5}=\mathrm{H} ; \mathrm{R}_{2}=\mathrm{CH}_{3} \mathrm{O} ; \mathrm{R}_{\boldsymbol{F}}=\mathrm{CH}_{3} \mathrm{CO}$ Aspidospermine

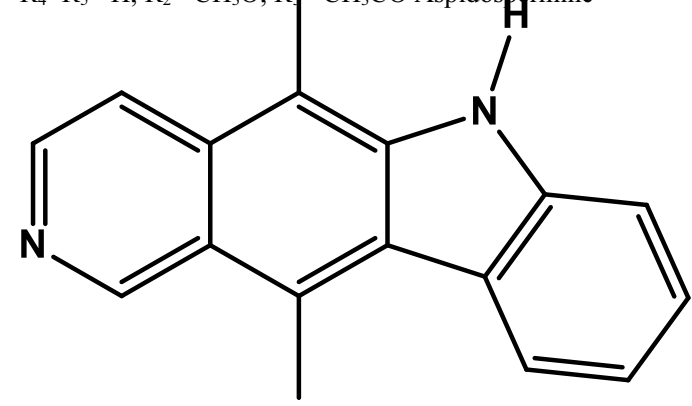

Ellipticine

(11) Apparicine

Fig. 4 Chemical structures of the indole alkaloids identified in Aspidosperma parvifolium trunk bark alkaloid extract 
Table 2 Antiplasmodial activity of ethanol bark extract of Aspidosperma parvifolium, fractions and uleine along with literature data for apparicine, aspidocarpine, and ellipticine

\begin{tabular}{|c|c|c|c|c|c|}
\hline \multirow{2}{*}{$\begin{array}{l}\text { Extract/fractions/ } \\
\text { compounds }\end{array}$} & \multicolumn{3}{|c|}{$\mathrm{IC}_{50}(\mu \mathrm{g} / \mathrm{mL})$ P. falciparum W2 } & \multicolumn{2}{|c|}{$\mathrm{IC}_{50}(\mu \mathrm{g} / \mathrm{mL})$ P. falciparum 3D7 } \\
\hline & MM & HM & HRPII & MM & HM \\
\hline Choroquine & $0.02 \pm 0.002$ & $0.018 \pm 0.0005$ & $0,0856 \pm 0.0201$ & $0.0013 \pm 0.0001$ & $0.002 \pm 0.0004$ \\
\hline Mefloquine & $0.016 \pm 0.002$ & $0.044 \pm 0.008$ & ND & $0.048 \pm 0.0007$ & $0.052 \pm 0.0006$ \\
\hline EEAP & $32.75 \pm 1.06$ & $42.51 \pm 6.33$ & $10,11 \pm 2,22$ & $20.51 \pm 0.70$ & $38.20 \pm 0.33$ \\
\hline EEAPA & $0.98 \pm 0.20$ & $8.0 \pm 1.19$ & $0.43 \pm 0.11$ & $7.63 \pm 0.31$ & $43.05 \pm 4.30$ \\
\hline EEAPN & $15.02 \pm 2.83$ & $38.02 \pm 3.76$ & $9,71 \pm 2,63$ & $17.75 \pm 0.35$ & $18.2 \pm 1.75$ \\
\hline Uleine & $0.75 \pm 0.10$ & $8.78^{\mathrm{a}}$ & $2.95 \pm 1.47$ & $11.90 \pm 0.10$ & ND \\
\hline Apparicine $^{b}$ & & $3.0 \pm 1.4$ & $3.2 \pm 2.7$ & & \\
\hline Aspidocarpine ${ }^{b}$ & & $5.4 \pm 2.5$ & $4.4 \pm 0.8$ & & \\
\hline Ellipticine ${ }^{c}$ & 0.018 & & & & \\
\hline
\end{tabular}

EEAP ethanol extract of Aspidosperma parvifolium trunk bark, EEAPA alkaloid fraction prepared from EEAP, EEAPN neutral fraction prepared from EEAP, MM microscopic method, $H M\left[{ }^{3} \mathrm{H}\right]$-hypoxanthine method, $N D$ not determined

a one triplicate experiment

b Ref. [36] P. falciparum W2

c Ref. [35] P. falciparum K1

Aspidosperma parvifolium were previously evaluated against $P$. falciparum [37, 38]. Ellipticine is the most active alkaloid amongst those shown in Table 2 but it is highly cytotoxic while uleine was not active against a panel of tumoral cells [18].

Uleine is a monoterpenoid indole alkaloid and its chemical structure can be related to those of quinine and synthetic quinoline anti-malarials, such as chloroquine, with the nitrogen of the indole unit corresponding to that of the quinoline system. These nitrogens are of low basicity. A second nitrogen, of a tertiary amine, and therefore of higher basicity, is present in both the systems. The quinoline system is the pharmacophore that plays a crucial role in the complexation to ferriprotoporphyrin IX (FPIX) resulting in inhibition of haemozoin formation and parasite growth. On the other hand, the presence of a basic amino group in the side chain is generally considered essential for trapping high concentrations of the drug in the acidic digestive vacuole of the parasite. It is known that these structural characteristics are important for the inhibition of the haem polymerization, the mechanism of action of quinolines as anti-malarials [39] and, possibly, of the monoterpenoid indole alkaloids, as well.

Recently, uleine was isolated from Aspidosperma olivaceum and its anti-malarial activity was also evaluated against the chloroquine-resistant strain W2 by the HRPII $\left(\mathrm{IC}_{50}=3.2 \pm 1.8 \mathrm{mg} / \mathrm{mL}\right)$ and the $\left[{ }^{3} \mathrm{H}\right]$-hypoxanthine $\left(\mathrm{IC}_{50}=7.0 \pm 0.0 \mathrm{mg} / \mathrm{mL}\right)$ assays [38]. These data confirm the results reported here and point to uleine as a novel anti- malarial hit.

\section{Citotoxicity and selectivity index (SI)}

The ethanol extract was not cytotoxic to Vero and HepG2 cell lines up to the concentrations of 500 and $1000 \mathrm{mg} /$ $\mathrm{mL}$, respectively. Fractionation of ethanol extract led to fractions of higher cytotoxicity (Table 3). The neutral fraction showed low cytotoxicity against both Hep G2A16 and Vero cell lines $\left(\mathrm{CC}_{50}=251.0\right.$ and $449.3 \mu \mathrm{g} /$

Table 3 Cytotoxicity of ethanol extract trunk bark of Aspidosperma parvifolium, derived fractions and uleine to Vero and HepG2 cells

\begin{tabular}{|c|c|c|c|c|c|c|}
\hline \multirow[t]{2}{*}{ Extract/fractions/compounds } & \multicolumn{3}{|l|}{ Vero cells } & \multicolumn{3}{|l|}{ HepG2 cells } \\
\hline & $\mathrm{CC}_{50}(\mu \mathrm{g} / \mathrm{mL})$ & SI W2 & SI 3D7 & $\mathrm{CC}_{50}(\mu \mathrm{g} / \mathrm{mL})$ & SI W2 & SI 3D7 \\
\hline EEAP & $>500$ & $>15.3$ & $>24.4$ & $>1000$ & 30.5 & 48.7 \\
\hline EEAPA & 299.7 & 305.8 & 39.3 & 74.4 & 75.9 & 9.7 \\
\hline EEAPN & 449.3 & 29.9 & 25.3 & 251.0 & 16.7 & 14.1 \\
\hline Uleine & 374.6 & 499.5 & 31.5 & 301.2 & 407.6 & 25.3 \\
\hline Chloroquine & ND & ND & $\mathrm{Nd}$ & 185.0 & 9250.0 & $142,307.7$ \\
\hline
\end{tabular}

EEAP ethanol extract of Aspidosperma parvifolium trunk bark, EEAPA alkaloid fraction prepared from EEAP, EEAPN neutral fraction prepared from EEAP, S/ selectivity index 
$\mathrm{mL}$, respectively). The alkaloid fraction was more cytotoxic to HepG2 $\left(\mathrm{CC}_{50} 74.4 \pm 15.5 \mu \mathrm{g} / \mathrm{mL}\right)$ than to Vero cells $\left(\mathrm{CC}_{50} 299.7 \mu \mathrm{g} / \mathrm{mL}\right.$ ) (Table 3 ). On the other hand, chromatographic fractionation of the alkaloid extract led to uleine that showed low cytotoxicity against both Hep G2A16 and Vero cell lines $\left(\mathrm{CC}_{50}=374.6\right.$ and $301.2 \mu \mathrm{g} / \mathrm{mL}$, respectively). The low cytotoxicity of uleine against 65 human cancer cell lines was previously reported [18]. Surprisingly, a higher cytotoxicity of uleine $\left(\mathrm{CC}_{50}=52 \pm 10.0 \mu \mathrm{g} / \mathrm{mL}\right)$ to HepG2 cell line was recently assigned [38]. The extract, neutral fraction and uleine disclosed high selectivity indexes (SI > 10) (Table 3) while lower selectivity was determined for the 3D7 chloroquine-sensitive strain of $P$. falciparum (SI < 10) (Table 3). In summary, uleine disclosed high SI and greater selectivity for the resistant strain W2, than the ethanol extract and the alkaloid fraction (Table 3).

When relating anti-malarial activity and cytotoxicity, it is noted that the fractionation performed was successful. Although no significant difference is observed between the $\mathrm{IC}_{50}$ values determined for uleine and the alkaloid fraction (Table 2), they are however quite distinct with respect to the cytotoxicity $\left(\mathrm{CC}_{50}\right)$, uleine being safer (less cytotoxic) (Table 3 ).

\section{Conclusion}

Ethanol extract of Aspidosperma parvifolium trunk bark afforded uleine that discloses high in vitro anti-malarial activity and selectivity against the chloroquine-resistant P. falciparum strain W2. Besides, the alkaloid fraction showed anti-malarial activity similar to uleine. However, uleine showed lower cytotoxicity and increased SI when compared to the alkaloid fraction. Uleine was demonstrated to be the major constituent in the alkaloid fraction of Aspidosperma parvifolium trunk bark and 15 other indole alkaloids have been identified along with uleine. The high chemical diversity of alkaloids from Aspidosperma species and the small number of these alkaloids that have been assayed for anti-malarial activity coupled to the traditional use of several species of this taxon to treat malaria in Brazil, as well as in other mesoand South American countries, make further investigations of plants in this genus of great interest in the quest for natural anti-malarial drugs [12].

\footnotetext{
Authors' contributions

MFD carried out the phytochemical work including isolation and characterization of uleine as part of her PhD thesis presented at PPGCF/UFMG/Belo Horizonte/Brazil. Antiplasmodial assays were performed by MFD under the supervision of MMP, with the collaboration of RCP and LFS. GCB and FDR are responsible for UPLC-PDA-MS/MS and HPLC-DAD studies. ABO conceived of the study, provided the plant material, supervised MFD, participated in its design and coordination and drafted the manuscript jointly with GCB, MFD and RCP. All authors read and approved the final manuscript.
}

\section{Author details}

1 Programa de Pós-Graduação em Ciências Farmacêuticas, Instituto de Ciências da Saúde, Universidade Federal do Pará, Belém, PA 66075-110, Brazil. ${ }^{2}$ Laboratório de Malária, Seção de Parasitologia, Instituto Evandro Chagas, Br-316, Km 7, s/n, B. Levilândia, Ananindeua, PA CEP 67030-000, Brazil. ${ }^{3}$ Escola de Farmácia, Universidade Federal de Ouro Preto, Ouro Preto, MG 35400-000, Brazil. ${ }^{4}$ Faculdade de Farmácia e Bioquímica, Universidade Federal de Juiz de Fora, Juiz de Fora, MG 38036-900, Brazil. ${ }^{5}$ Faculdade de Farmácia, Universidade Federal de Minas Gerais, Av. Antônio Carlos, 6627, Pampulha, Belo Horizonte, MG 31270-901, Brazil.

\section{Acknowledgements}

The authors gratefully acknowledge the financial support from the Conselho Nacional de Desenvolvimento Científico e Tecnológico-CNPq, (PRONEX Process 555655/2009-1) and Fundação de Amparo à Pesquisa do Estado de Minas Gerais_FAPEMIG (PRONEX Process CDS APQ 01129-10).

\section{Competing interests}

The authors declare that they have no competing interests.

Received: 8 July 2015 Accepted: 18 November 2015

Published online: 10 December 2015

\section{References}

1. WHO. World malaria report 2014. World Health Organization, Geneva. 2014. http://www.who.int/malaria/publications/ world_malaria_report_2014/report/en/.

2. Dondorp AM, Yeung S, White L, Nguon C, Day NPJ, Socheat D, et al. Artemisinin resistance: current status and scenarios for containment. Nat Rev Microbiol. 2010;8:272-80.

3. WHO. Status report on artemisinin resistance. In: Global malaria program. Geneve. 2014. http://www.who.int/malaria/publications/atoz/status_ rep_artemisinin_resistance_jan2014.pdf.

4. Ginsburg H, Deharo E. A call for using natural compounds in the development of new antimalarial treatments - an introduction. Malar J. 2011;10:1-7.

5. Kaur K, Jain M, Kaur T, Jain R. Antimalarials from nature. Bioorg Med Chem. 2009;17:3229-56.

6. Wright CW. Recent developments in research on terrestrial plants used for the treatment of malaria. Nat Prod Rep. 2010;27:961-8.

7. Milliken W, Albert B. The use of medicinal plants by the Yanomami Indians of Brazil. Econ Bot. 1996;50:10-25.

8. Dolabela MF, Oliveira SG, Peres JM, Nascimento JM, Povoa MM, Oliveira $A B$. In vitro antimalarial activity of six Aspidosperma species from the state of Minas Gerais (Brazil). An Acad Bras Cienc. 2012;84:899-910.

9. Mariath IR, Falcão HS, Barbosa-Filho JM, Sousa LCF, Tomaz ACA, Batista LM, et al. Plants of the American continent with antimalarial activity. Braz J Pharmacog. 2009;19:158-91.

10. Milliken W, Albert B. The use of medicinal plants by the Yanomami Indians of Brazil. Part II. Econ Bot. 1997;51:264-78.

11. Oliveira AB, Dolabela MF, Braga FC, Jacome RL, Varotti FP, Povoa MM. Plant-derived antimalarial agents: new leads and efficient phythomedicines. Part I. Alkaloids. An Acad Bras Cienc. 2009;81:715-40.

12. De Paula RC, Dolabela MF, Oliveira AB. Aspidosperma species as sources of antimalarials. Part III. A review of traditional use and antimalarial activity. Planta Med. 2014;80:378-86.

13. Lorenzi H. Árvores brasileiras: manual de identificação e cultivo de plantas arbóreas nativas do Brasil. 2nd ed. Nova Odessa: Instituto Plantarum; 1998.

14. Almeida MR, Lima JA, dos Santos NP, Pinto AC. Pereirina: o primeiro alcalóide isolado no Brasil? Braz J Pharmacog. 2009;19:942-52.

15. Jácome RLRP, Oliveira AB, Raslan DS, Wagner H. Chemical constituents and chromatographic profile of the stem bark of Aspidosperma parvifolium A. DC. (" pau-pereira"). Quim Nova. 2004;27:897-900.

16. Souza WM, Brehmer F, Nakao LS, Stinghen AE, Santos CA. Ação da uleína sobre a produção de óxido nítrico em células RAEC e B16F10. Rev Bras Farmacogn. 2007;17:191-6. 
17. Seidl C, Correia BL, Stinghen AE, Santos CA. Acetylcholinesterase inhibitory activity of uleine from Himatanthus lancifolius. Z Naturforsch C. 2010;65:440-4.

18. PubChem Substance. 2013. http://pubchem.ncbi.nlm.nih.gov/ substance/115962\#x299. Accessed 23 May 2013.

19. Trager W, Jensen JB. Human malaria parasites in continuous culture. Science. 1976;193:673-5.

20. Lambros C, Vanderberg JP. Synchronization of Plasmodium falciparum erythrocytic stages in culture. J Parasitol. 1979; 418-20.

21. Rieckmann KH, Campbell GH, Sax LJ, Mrema JE. Drug sensitivity of Plasmodium falciparum. An in vitro microtechnique. Lancet. 1978;1:22-3.

22. Huber W, Koella JC. A comparison of three methods of estimating EC50 in studies of drug resistance of malaria parasites. Acta Trop. 1993:55:257-61.

23. Dolabela MF. Atividade antiplasmódica e citotoxicidade de Esenbeckia febrifuga (A.St-Hil.) Juss. ex Mart. (Rutaceae) e de espécies do gênero Aspidosperma (Apocynaceae) [PhD thesis] 2007.

24. Desjardins RE, Canfield CJ, Haynes JD, Chulay JD. Quantitative assessment of antimalarial activity in vitro by a semiautomated microdilution technique. Antimicrob Agents Chemother. 1979;16:710-8.

25. de Madureira MDC, Martins AP, Gomes M, Paiva J, da Cunha AP, do Rosário V. Antimalarial activity of medicinal plants used in traditional medicine in S, Tomé and Prıncipe islands. J Ethnopharmacol. 2002;81:23-9.

26. Noedl H, Bronnert J, Yingyuen $\mathrm{K}$, Attlmayr B, Kollaritsch H, Fukuda M. Simple histidine-rich protein 2 double-site sandwich enzyme-linked immunosorbent assay for use in malaria drug sensitivity testing. Antimicrob Agents Chemother. 2005;49:3575-7.

27. Mosmann T. Rapid colorimetric assay for cellular growth and survival: application to proliferation and cytotoxicity assays. J Immunol Methods. 1983;65:55-63.

28. Mitaine-Offer AC, Sauvain M, Valentin A, Callapa J, Mallie M, ZechesHanrot M. Antiplasmodial activity of Aspidosperma indole alkaloids. Phytomed. 2002;9:142-5.

29. Sangster AW, Stuart KL. Ultraviolet spectra of alkaloids. Chem Rev. 1965;65:69-130.
30. Churchwell MI, Twaddle NC, Meeker LR, Doerge DR. Improving LC-MS sensitivity through increases in chromatographic performance: comparisons of UPLC-ES/MS/MS to HPLC-ES/MS/MS. J Chromatogr B Analyt Technol Biomed Life Sci. 2005:825:134-43.

31. Aguiar GP, Wakabayashi KA, Luz GF, Oliveira VB, Mathias L, Vieira IJ, et al. Fragmentation of plumeran indole alkaloids from Aspidosperma spruceanum by electrospray ionization tandem mass spectrometry. Rapid Commun Mass Spectrom. 2010;24:295-308.

32. Biemann K. Four decades of structure determination by mass spectrometry: from alkaloids to heparin. J Am Soc Mass Spectrom. 2002;13:1254-72.

33. Joule JA, Ohashi M, Gilbert B, Djerassi C. Alkaloid studies. 53. The structures of nine new alkaloids from Aspidosperma dasycarpon A. DC. Tetrahedron. 1965;21:1717-34.

34. Li-Mei L, Guo-You L, Dong-Mei F, Zhi-Jun W, Guo-Lin Z. Analysis of monoterpenoid indole alkaloids using electrospray ionization tandem mass spectrometry. Chem Nat Comp. 2015;51:116-20.

35. Pereira MM, Jacome R, Alcântara A, Alves RB, Raslan DS. Alcalóides indólicos isolados de espécies do gênero Aspidosperma (Apocynaceae). Quim Nova. 2007;30:970-83

36. Borris RP, Lankin DC, Cordell GA. Studies on the uleine alkaloids I. carbon-13 nmr studies on uleine, 20-epiuleine and (4S)-uleine-Nb-oxide. J Nat Prod. 1983;46:200-5.

37. Andrade-Neto VF, Pohlit AM, Pinto AC, Silva EC, Nogueira KL, Melo MR, et al. In vitro inhibition of Plasmodium falciparum by substances isolated from Amazonian antimalarial plants. Mem Inst Oswaldo Cruz. 2007;102:359-65.

38. Chierrito TP, Aguiar AC, de Andrade IM, Ceravolo IP, Goncalves RA, de Oliveira AJ, et al. Anti-malarial activity of indole alkaloids isolated from Aspidosperma olivaceum. Malar J. 2014;13:142.

39. Yearick K, Ekoue-Kovi K, Iwaniuk DP, Natarajan JK, Alumasa J, de Dios AC, et al. Overcoming drug resistance to heme-targeted antimalarials by systematic side chain variation of 7-chloro-4-aminoquinolines. J Med Chem. 2008;51:1995-8

\section{Submit your next manuscript to BioMed Central and we will help you at every step:}

- We accept pre-submission inquiries

- Our selector tool helps you to find the most relevant journal

- We provide round the clock customer support

- Convenient online submission

- Thorough peer review

- Inclusion in PubMed and all major indexing services

- Maximum visibility for your research

Submit your manuscript at www.biomedcentral.com/submit

\section{(O) Biomed Central}

